\title{
PENGARUH PENDIDIKAN ALAM BEBAS TERHADAP KESADARAN KELESTARIAN LINGKUNGAN
}

\author{
Dea Misqiyatul Masluhah, Etty Ratnawati \\ IAIN Syekh Nurjati Cirebon \\ misqiyatuldea@syekhnurjati.ac.id; ettyratnawati@syekhnurjati.ac.id
}

\begin{abstract}
Strategi dan model pembelajaran yang digunakan oleh guru kurang terutama didalam kelas yang mengakibatkan siswa merasa jenuh dan bosan dan siswa pun tidak dilatih untuk berfikir kreatif, membebaskan diri siswa dalam mengembangkan imajinasi dan wawasan sehingga siswa kurang mampu untuk memahami keadaan dan cara melestarikan yang ada di lingkungan sekolahnya. Penelitian ini bertujuan untuk mengetahui penerapan pedidikan alam bebas, kesadaran kelestarian lingkungan dan untuk mengetahui seberapa besar pengaruh pendidikan alam bebas terhadap kesadaran kelestarian lingkungan di MTs Negeri 6 Cirebon Kabupaten Cirebon. Pendidikan luar kelas (outdoor education) merupakan aktivitas luar sekolah yang berisi kegiatan di luar kelas atau sekolah dan di alam bebas lainnya. Untukitu, proses pembelajaran di luar kelas juga dapat menumbuhkan kesadaran kelestarian lingkungan yang merupakan sumber daya alam yang seharusnya dijaga dan dilestarikan. Jenis penelitian adalah penelitian korelasional regresi dengan pendekatan kuantitatif. Populasi dalam penelitian ini adalah sebanyak 390 siswa. Teknik pengumpulan data dilakukan dengan observasi, wawancara, angket dan dokumentasi. Teknik analisis data menggunakan uji presentase, uji normalitas, uji homogenitas, uji koefisien korelasi, uji koefisien determinasi, uji regresi, dan uji hipotesis. Hasil penelitian dapat disimpulkan bahwa berdasarkan rekapitulasi angket bahwa pendidikan alam bebas berada pada rentang $83 \%$ dengan kategori (sangat baik). Sedangkan kesadaran kelestarian lingkungan berada pada rentang $85 \%$ dengan kategori (sangat baik). Berdasarkan hasil dari uji korelasi antara variabel X dan Y adalah sebesar 0,770 dengan taraf sig. $=0,05$ diperoleh signifikansi (Sig.2-tailed) sebesar 0,000 artinya terdapat hubungan yang positif dan sedang atau cukup antara variabel $\mathrm{X}$ dan $\mathrm{Y}$ dan pada koefisien determinasi besarnya konstribusi pendidikan alam bebas terhadap kesadaran kelestarian lingkungan adalah 59,3\%. Berdasarkan hasil uji hipotesis diperoleh sig (2-tailed) $0,00<0.05$, maka keputusannya adalah $\mathrm{H}_{\mathrm{a}}$ diterima artinya bahwa terdapat pengaruh yang signifikan antara pendidikan alam bebas terhadap kesadaran kelestarian lingkungan di MTs Negeri 6 Cirebon.
\end{abstract}

Kata Kunci: Strategi, Pendidikan Alam Bebas (Outdoor), Kesadaran

Jurnal Edueksos Vol.VIII, No. 2, Desember 2019 


\begin{abstract}
Strategies and learning models used by the teacher are lacking especially in the classroom which results in students feeling bored and students are not trained to think creatively, free themselves in developing imagination and insight so students are less able to understand the conditions and ways of preserving the environment school.This study aims to determine the application of free education, awareness of environmental sustainability and to find out how much influence the education of the outdoors on environmental sustainability awareness in state MTs Negeri 6 Cirebon Kabupaten Cirebon.Outside class education is an activity outside of school that contains activities outside the classroom or school and other outdoors. Therefore, the learning process outside the classroom can also foster awareness of environmental sustainability which is a natural resource that must be preserved and preserved.This type of research is correlational regression research with a quantitative approach. The population in this study were 390 students. Data collection techniques are carried out by observation, interviews, questionnaires and documentation. Data analysis techniques use percentage test, normality test, homogeneity test, correlation coefficient test, test coefficient of determination, regression test and hypothesis test. The results of the study can be concluded that based on the recapitulation of the free education questionnaire in the range of $83 \%$ with the category (very good). While environmental sustainability awareness is in the range of $85 \%$ with the category (very good). based on the test results the correlation between variables $X$ and $Y$ is equal to0.770 with the level of sig. $=0.05$ obtained significance of 0,000 means that there is a positive and moderate or sufficient relationship between variables $X$ and $Y$ and in the large coefficient of determination the contribution of free education to environmental sustainability awareness is $59.3 \%$ based on the results of hypothesis testing obtained sig. $0.00<0.05$, then the decision is $H_{a} a c c e p t e d m e a n i n g$ that there is a significant influence between natural education on environmental sustainability awareness in state MTs Negeri 6 Cirebon.
\end{abstract}

\title{
Keywords: Outdoor Education, Environmental Sustainability Awareness
}

\section{A. PENDAHULUAN}

Pendidikan adalah pengalaman-pengalaman belajar terprogram dalam bentuk pendidikan formal, nonformal dan informal di sekolah dan luar sekolah yang berlangsung seumur hidup, yang bertujuan untuk mengoptimalisasi kemampuan-kemampuan individu. Mengenai hal ini, Mudyahardjo (2006:3) menyatakan bahwa : "Pendidikan adalah hidup". Pendidikan adalah segala pengalaman belajar yang berlangsung dalam segala lingkungan dan sepanjang hidup. Pendidikan adalah segala situasi hidup yang mempengaruhi pertumbuhan dan perkembangan hidup".

Jurnal Edueksos Vol.VIII, No. 2, Desember 2019

The journal of social and economics education 
Tujuan pendidikan bangsa Indonesia sebagaimana tertera dalam undangundang RI Nomor 20 tahun 2003 : "Pendidikan sebagai usaha sadar dan terencana untuk mewujudkan suasana belajar dan proses pembelajaran sehingga peserta didik secara aktif mengembangkan potensi dirinya untuk memiliki kekuatan spiritual keagamaan, pengendalian diri, kepribadian, kecerdasan, akhlak mulia, serta keterampilan yang diperlukan di masyarakat, bangsa dan negara". Pendidikan adalah fungsi utama dalam pembentukan pribadi manusia, pendidikan sangat berperan dalam membentuk baik dan buruknya pribadi manusia. Proses perkembangan dan pendidikan manusia tidak hanya terjadi dipengaruhi oleh proses pendidikan yang ada dalam pendidikan formal saja, akan tetapi dipengaruhi juga oleh lingkungan pendidikan.

Pendidikan alam bebas ini bias dikatakan dengan proses pembelajaran outdoor yang perlu diterapkan di setiap sekolah agar peserta didik tidak merasa bosan maupun jenuh selama proses pembelajaran. Dan lingkungan pendidikan pun berpengaruh dalam segala sesuatu yang ada disekitar, baik berupa benda mati, makhluk hidup ataupun peristiwa-peristiwa yang terjadi termasuk kondisi masyarakat terutama yang dapat memberikan pengaruh kuat kepada individu seperti lingkungan tempat pendidikan berlangsung dan lingkungan tempat anak bergaul.

Akan tetapi, dalam pengembangan fasilitas dan sumber belajar, pendidik harus mampu membuat siswa aktif dalam pembelajaran dan juga harus berinisiatif mendayagunakan lingkungan sekitar sekolah sebagai sumber belajar yang lebih kongkrit dan siswa yang masih enggan untuk meningkatkan kesadaran dalam kelestarian lingkungan di sekolahnya. Pendayagunaan lingkungan sebagai sumber belajar, misalnya memanfaatkan batu-batuan, tanah, tumbuh-tumbuhan, keadaan alam, pasar, kondisi sosial, ekonomi, dan budaya kehidupan yang berkembang di masyarakat. Untuk kepentingan tersebut, perlu senantiasa di upayakan peningkatan pengetahuan guru dan di dorong terus menjadi guru yang kreatif, inovatif dan profesional, terutama 
dalam pengadaan serta pendayagunaan fasilitas dan sumber belajar secara luas, untuk mengembangkan kemampuan peserta didik secara optimal.

Oleh karena itu seorang pendidik harus selalu mempunyai banyak cara untuk mengembangkan kreatifitas dan keaktifan peserta didik serta meningkatkan hasil belajar pesertadidik, guru harus memilih strategi belajar yang tepat sehingga pembelajaran dapatditerima oleh siswa.

Selama peneliti melakukan observasi di MTs Negeri 6 Cirebon Kabupaten Cirebon, peneliti menemukan banyak masalah terkait proses pembelajaran, diantaranya lemahnya proses pembelajaran terutama di dalam kelas yang mengakibatkan siswa merasa jenuh dan bosan, strategi dan model pembelajaran yang digunakan oleh guru di sekolah tersebut maupun proses hukuman yang diberikan guru terhadap siswa yang bermasalah. Seperti dalam metode pembelajaran IPS di MTs Negeri 6 Cirebon. Kabupaten Cirebon yang masih menggunakan metode konvensional sehingga siswa tidak dapat berkembang dan hanya berfokus pada materi yang disampaikan oleh guru. Siswa pun tidak dilatih untuk berfikir kreatif dan membebaskan diri mereka dalam mengembangkan imajinasi dan wawasan agar dapat memecahkan masalah yang sedang dihadapi baik dalam setiap aktivitas belajar maupun sehari-hari. Oleh karena itu, perlu melakukan upaya pengembangan pembelajaran yang inspiratif, inovatif, menantang dan menyenangkan atau dapat memberikan respon positif belajar kepada siswa untuk meningkatkan proses dan hasil belajar baik untuk meningkatkan kesadaran kelestarian lingkungan yang dilakukan secara mandiri atau kelompok. Dalam penelitian ini, kajian diarahkan pada pengungkapan Pengaruh Pendidikan Alam Bebas Terhadap Kesadaran Kelestarian Lingkungan Di Mts Negeri 6 Cirebon Kabupaten Cirebon“.

\section{B. KAJIAN TEORI}

Pendidikan alam bebas merupakan suatu kegiatan menyampaikan pelajaran diluar kelas. Pendidikan luar kelas (outdoor education) merupakan aktivitas luar sekolah yang berisi kegiatan di luar kelas atau sekolah dan di 
alam bebas lainnya.Pendidikan luar kelas tidak sekedar memindahkan pelajaran keluar kelas, tetapi dilakukan dengan mengajak siswa menyatu dengan alam dan melakukan beberapa aktivitas yang mengarah pada terwujudnya perubahan perilaku siswa terhadap lingkungan melalui tahaptahap penyadaran, tanggung jawab atau tingkah laku. (Diunduh dari https://ejournal.upi.edu/index.php/penjas pada tanggal 26 Juni 2019 pukul 19:30 WIB). Dalam pelaksanaan guru harus bias membangkitkan atau membangun motivasi siswa terhadap hal yang akan dipelajari diluar kelas, serta cara menggerakan tingkah laku siswa diluar kelas. Jika guru mampu bersikap demikian, maka siswa bias mendapatkan motivasi penuh dalam pembelajaraan diluar kelas yang menunjukkan minat, semangat, dan ketekunan yang tinggi dalam pembelajaran yang diberikan diluar tanpa mengurangi keseriusan dan belajar karena factor alam bebas.

Kesadaran adalah siuman atau sadar akan tingkah lakunyayaitu pikiran sadar yang mengatur akal dan dapat menentukan pilihan terhadap yang diinginkan misalnya baik, buruk, dan lain sebaginya. (Joseph Murphy, 2002 : 33). Kesadaran lingkungan hidup yang baik dan sehat menggugah berbagai lembaga untuk melakukan penanganan. Kepedulian yang ditunjukkan tidak lagi terbatas pada kondisi local atau batas wilayah, namun mengglobal. (Helmi, 2013:61). Kesadaran lingkungan hidup menyangkut pengelolaan perilaku makhluk hidup, terutama sikap, kelakuan, dan berbagai sepak terjang manusia dalam menunjang kualitas hidup yang sangat diperlukan demi terciptanya lingkungan hidup yang harmonis dan lestari dengan tindakan-tindakan yang positif.

Menurut Helmi (2013:44) Kelestarian lingkungan adalah setiap orang memikul kewajiban dan tanggungjawab terhadap generasi dengan melakukan upaya pelestarian daya dukung ekosistem dan memperbaiki kualitas lingkungan hidup. Untuk itu kita sebagai manusia harus menyadari bahwa lingkungan merupakan sarana pengembangan hidup yang harus dijaga kelestariannya, perlindungan dari kemusnahan dan kerusakan, pengawetan dan pengelolan lingkungan yang menjamin pemanfaatnya secara bijaksana dan 
menjadi kesinambungan persediaannya dengan tetap memelihara dan meningkatkan kualitas dan keanekaragamannya.

Menurut Hafied Canggara (2002:163) mengatakan bahwa pengaruh atau efek ialah perbedaan antara apa yang dipikirkan, dirasakan, dan dilakukan oleh penerima sebelum dan sesudah menerima pesan. Pendidikan alam bebas merupakan pendidikan yang menggunakan proses pembelajaran di luar kelas. Pengaruh pendidikan alam bebas dengan kesadaran pelestarian lingkungan ini memiliki pengaruh yang sangaterat, dimana dengan adanya pendidikan alam bebas siswa akan lebih terlatih dan menyadari pentingnya lingkungan hidup di sekitarnya dan menjaga akan kelestarian yang ada di lingkungannya.

\section{METODE PENELITIAN}

Penelitian ini menggunakan pendekatan kuantitatif korelasional regresi, karena penelitian ini menggunakan ukuran-ukuran nominal (angket) dalam pengumpulan data dan analisis datanya. Peneliti menggunakan The one-shot case study dalam desain ini yang menggunakan satu kelompok dikarenakan perlakuan tertentu (variabel bebas), kemudian dilakukan pengukuran terhadap variabel terikatnya. Penelitian ini dilaksanakan di MTs Negeri 6 Cirebon. Populasi dalam penelitian ini adalah siswa kelas VII MTs Negeri 6 Cirebon berjumlah 390Siswa. Dengan menggunakan teknik sampel cluster (Cluster Sampling). Untuk menentukan sample dengan cara undi (koclokan) yang akan menjadi kelas eksperimen. Jadi jumlah keseluruhan siswa kelas VII sebanyak 390 yang akan di jadikan kelas eksperimen yaitukelas VII J (32 Siswa) hasil dari undi (koclokan) yang sudah ditentukan oleh penelitian.

Variabel bebas atau independent variable $(\mathrm{X})$ adalah pendidikan alam bebas. Variabel terikat dependent variable (Y) adalah kesadaran kelestarian lingkungan. Uji validitas adalah kebenaran dan keabsahan instrumen penelitian yang digunakan. Reliabilitas dilakukan untuk mendapatkan tingkat ketetapan alat pengumpulan data yang digunakan.

Teknik yang digunakan untuk mengumpulkan data dalam penelitian ini yaitu: Observasi, wawancara, kuesioner (Angket), dokumentasi. Teknik 
Analisis Data menggunakan; a) Teknik Prosentase, b) Uji Normalitas, c) Uji Homogenitas d) Uji Koefisien Korelasi, e) Uji Koefisien Determinasi, f) Uji Regresi, g) Uji Hipotesis. Setelah diketahui koefisien determinasi, langkah selanjutnya adalah uji hipotesis yaitu (Uji-t) untuk memberikan kesimpulan dengan menggunakan rumus setelah didapat $\left(r_{x y}\right)$ pengujian koefisien korelasi dengan rumus product moment ini, maka menggunakan Uji-t untuk memberikan kesimpulan mengenai apakah terdapat pengaruh yang signifikan atau tidak signifikan.

\section{HASIL DAN PEMBAHASAN}

1. Hasil Penelitian

a. Penerapan Pendidikan AlamBebas

Berdasarkaan data yang diperoleh dari 32 responden dengan jumlah item angket sebanyak 20 maka skor ideal untuk angket tersebut adalah 20 item x 32 responden x 4 (skor tertinggi tiap item) $=2560$. Diketahui jumlah skor total sesuai dengan data penyebaran angket tentang penerapan pendidikan alam bebas di MTs Negeri 6 Cirebon Kabupaten Cirebon adalah sebesar 2114. Presentase angket dapat dihitung dengan rumus sebagai berikut:

Diketahui : $\quad$ Skor total hasil angket $=2114$

Standar skor tertinggi $=2560$

Jadi, persentase angket:

$$
\frac{2114}{2560} \times 100 \%=83 \%
$$

Kesimpulannya adalah penerapan pendidikan alam bebas pada pembelajaran IPS termasuk dalam kategori sangat baik yang berada di antara $81 \%$ 100\%karena rata-rata siswa menjawab sangat setuju dan setuju.

b. Kesadaran Kelestarian Lingkungan

Berdasarkaan data yang diperolehdari 32 responden dengan jumlah item angket sebanyak 20 maka skor ideal untuk angket tersebut adalah 20 item x 32 responden x 4 (skor tertinggi tiap item $)=2560$. Diketahui jumlah skor total sesuai dengan data penyebaran angket tentang Kesadaran 
Kelestarian Lingkungan di MTs Negeri 6 Cirebon Kabupaten Cirebon adalah sebesar 2168. Presentase angket dapat dihitung dengan rumus sebagai berikut:

Diketahui: Skor total hasil angket $=2168$

$$
\text { Standar skor tertinggi }=2560
$$

Jadi, persentase angket:

$$
\frac{2168}{2560} \times 100 \%=85 \%
$$

Skor tersebut tergolong pada kategori sangat baik yang berada di antara $81 \%-100 \%$

c. Pengaruh Pendidikan Alam Bebas Terhadap Kesadaran Kelestarian Lingkungan.

Tabel 1

Correlations

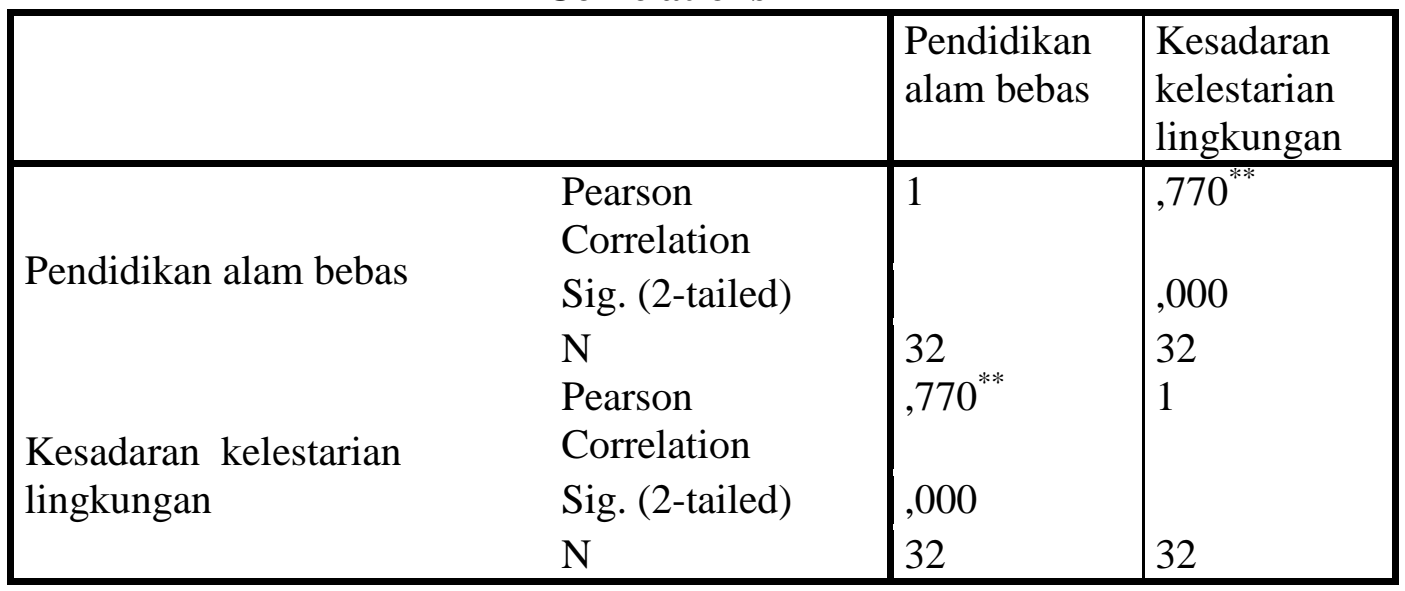

${ }^{* *}$. Correlation is significant at the 0.01 level (2-tailed).

Berdasarkan table hasil SPSS 22 di atas bahwa diketahui output yang diperoleh untuk pengujian koefisien korelasi jika nilai sig.<dari 0,05 maka berkolerasi atau terdapat hubungan, jika nilai sig. >dari 0,05 maka data tersebut tidak berkorelasi atau tidak adanya hubungan. Adapun nilai sig. Pendidikan alam bebas terhadap kesadaran kelestarian lingkungan sig. Sebesar $0,00<0,05$ artinya dari kedua variable tersebut berkolerasi atau adanya hubungan antara dua variabel. 
Kemudian melihat pedoman koefisen korelasi berdasarkan tingkat penafsiran korelasi sebagai berikut:

Tabel 2

Penafsiran Koefisien Korelasi

\begin{tabular}{|l|l|}
\hline $\begin{array}{l}\text { Batasan Penafsiran Koefisien } \\
\text { Korelasi }\end{array}$ & Kriteria Koefisien Korelasi \\
\hline Antara $0,00-0,45$ & Korelasi yang sangat rendah \\
\hline Antara $0,46-0,63$ & Korelasi yang sangat lemah \\
\hline Antara $0,64-0,77$ & Korelasi yang sedang atau cukup \\
\hline Antara $0,78-0,89$ & Korelasi yang tinggi \\
\hline Antara $0,90-1,00$ & Korelasi yang sangat tinggi \\
\hline
\end{tabular}

Nilai person korelasi hubungan antara pendidikan alam bebas terhadap terhadap kesadaran kelestarian lingkungan sebesar 0,770 artinya tingkat hubungan termasuk kategori sedang atau cukup adanya korelasi.

Tabel 3

Coefficients $^{\mathrm{a}}$

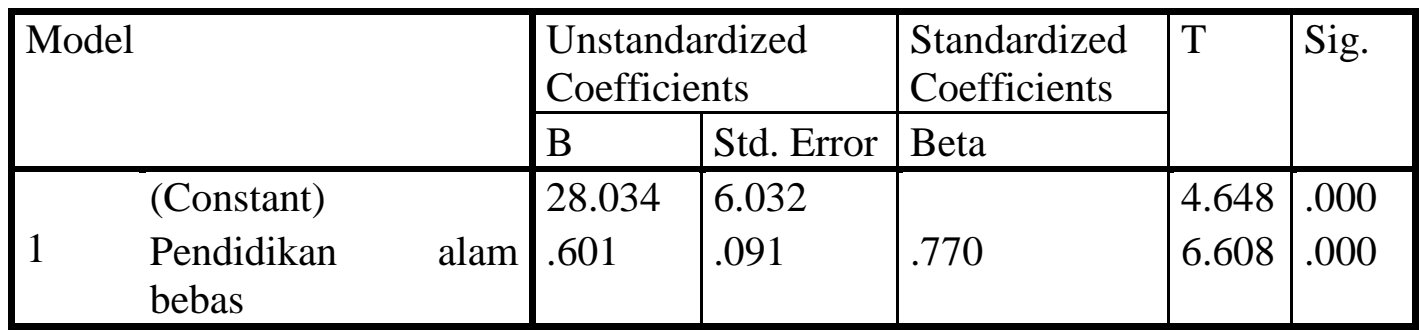

a. Dependent Variable: kesadaran kelestarian lingkungan

$\hat{Y}=a+b X$

$\hat{Y}$ adalah variabel dependent, dalam hal ini adalah kesadaran kelestarian lingkungan, dan $\mathrm{X}$ adalah variabel independent, dalam hal ini adalah Pendidikan alam bebas. Sedangkan a dan $b$ adalah nilai konstanta yang dicari. Berdasarkan hasil regrasi diketahui nilai constant-nya adalah 28,034 dan nilai koefisien pendidikan alam bebas adalah 0,601. Dari 
keterangan tersebut kita dapat memperoleh persamaan regresi sebagai berikut:

$$
\hat{Y}=28,034+0,601 \mathbf{X}
$$

Nilai konstanta dari koefisien regresi sebesar 28,034, hal ini menyatakan bahwa jika tidak ada kenaikan nilai atau skor dari variabel pendidikan alam bebas, maka variabel kesadaran kelestarian lingkungan adalah 28,034. Koefisien regresi variable pendidikan alam bebas sebesar 0,601 menyatakan bahwa setiap terjadi penambahan skor variable pendidikan alam bebas akan dapat menambah kenaikan skor variable kesadaran kelestarian lingkungan sebesar 0,601.

\section{E. KESIMPULAN}

Pengaruh pendidikan alam bebas terhadap kesadaran kelestarian lingkungan pada pembelajaran IPS kelas VII J di MTs Negeri 6 Cirebon dapat disimpulkan bahwa siswa sangat antusias dalam pendidian alam bebas pada pembelajaran IPS kelas VII J di MTs Negeri Kabupaten Cirebon dapat diketahui berdasarkan angket yang telah disebarkan kepada siswa. Secara keseluruhan menunjukan bahwa siswa mayoritas menjawab sangat setuju dan setuju yaitu sebesar 83\%. Angka ini berada diantara 81\%-100\% yang dikategorikan sangat baik.Bahwa kategori sangat baik, siswa sangat aktif, kreatif, mengembangkan sikap mandiri, dan keterampilan bekerja kelompok saat proses pembelajaran berlangsung.

Kesadaran kelestarian lingkungan dapat dikategorikan sangat baik dalam arti untuk kesadaran kelestarian ini sudah maksimal. Hal ini dapat dilihat dari skor hasil rata-rata responden siswa yang menjawab pada item angket yang terdiri dari 32 siswa menyatakan setuju dengan persentase 85\%, Angka ini berada diantara 81\%-100\% yang dikategorikan sangat baik. Bahwa kategori sangat baik, siswa memiliki kepedulian, meningkatkan penataan lingkungan, meningkatkan upaya harmonisasi.

Terdapat pengaruh antara pendidikan alam bebas terhadap kesadaran kelestarian lingkungan. Hasil output SPSS 22 di atas dapat dilihat uji korelasi 
hubungan antara pendidikan alam bebas terhadap terhadap kesadaran kelestarian lingkungan sebesar 0,770 artinya tingkat hubungan termasuk kategori sedang atau cukup adanya korelasi dan uji regresi bahwa koefisien regresi $\mathrm{x}$ sebesar 0,601 menyatakan bahwa setiap penambahan $1 \%$ nilai pendidikan alam bebas, maka nilai kesadaran kelestarian lingkungan bertambah sebesar 0,601. hipotesis yang di terima sesuai dengan uji t diketahui darinilai Sig $0,00<0.05$, dengan nilai koefisien regresi 0,601 , maka keputusannya adalah $\mathrm{H}_{\mathrm{a}}$ diterima artinya bahwa terdapat pengaruh yang signifikan antara pendidikan alam bebas terhadap kesadaran kelestarian lingkungan di MTs Negeri 6 Cirebon.

\section{DAFTAR PUSTAKA}

Andi. 2014. Analisis Data Penelitian dengan SPSS 22. Yogyakarta :Wahana Komputer.

Arifin, Zainal. 2014. Penelitian Pendidikan. Bandung :RemajaRosdakarya.

Asti, Badiatul Muchlisin. 2009. Fun Out Bound. Yogyakarta : Diva Press.

Azwar, Saifuddin. 2010. Reliabilitas dan Validitas. Yogyakarta :PustakaPelajar.

Baharuddin \& Wahyuni, Esa Nur, 2008. Teori Belajar dan Pembelajaran.Yogyakarta :Ar-Ruzz Media.

Canggara, Hafied. 2002. Konsep Pengaruh Pendidikan. Yogyakarta : AR-Ruzz Media.

Fadhilah, Jihan, Nur. 2018. Penerapan Metode Outdoor Learning Dengan Memanfaatkan Taman Sekolah Sebagai Sumber Belajar Untuk Meningkatkan Hasil Belajar Siswa Pada Konsep Spermatopyta di MAN 1 Cirebon.Skripsi IAIN Syekh Nurjati Cirebon.

Hasbullah. 2003. Dasar-Dasar Ilmu Pendidikan.Jakarta : Raja GrafindoPersada.

Helmi.2013. Hukum Perizinan Lingkungan Hidup. Jakarta :Sinar Grafika.

Husamah. 2013. PembelajaranLuar Kelas Outdoor Learning. Jakarta :Prestasi Pustakarya.

Iskandar, Zulrizka. 2012 .Psikolog Lingkungan Teori dan Konsep. Bandung :Refika Aditama.

Irianto, Agus. 2012. Statistik. Perpustakaan Nasional :Kencana. 
Ketut, Istiqomah. 2011. Kebersamaan Menjaga Alam. Bandung :Abhiseka.

Kurnia Eka, Yogi Akin, Oyok Nurjatnika, Implementasi Pendidikan Luar Sekolah (Outdoor Education) Terhadap Pembentukan Karakter Siswa Sekolah Dasar, Jurnal Pendidikan Jasmani Dan Olahraga, Vol.9 No. 1,April 2017. diakses dan di download pada tanggal 26 Juni 2019 pukul 19:30 WIB

Marzuki, Saleh. 2010. Pendidikan Nonformal.Surakarta :Remaja Rosdakarya.

Mudyahardjo, Radja. 2006. Pengantar Pendidikan Sebuah Studi Awal Tentang Dasar-Dasar Pendidikan Pada Umumnya Dan Pendidikan Indonesia. Jakarta: Raja GrafindoPersada.

Muhidin, Sambas Ali dan Maman Abdurahman. 2011. Analisis Korelasi, Regresi, dan Jalur dalam Penelitian. Bandung: Pustaka Setia.

Nurhakim, Lukman. 2015. Pengaruh Pemanfaatan Lingkungan Sekolah terhadap Hasil Belajar Siswa SMPN 2 Cikande dalam Konsep Interaksi Makhluk Hidup dengan Lingkungan. Skripsi IAIN Syekh Nurjati Cirebon.

Nurismayani, Resty, Fadlia .2016. Penerapan Metode Outdoor Learning Untuk Meningkatkan Efektivitas Dan Hasil Belajar Siswa Pada Pembelajaran IPS Kelas VIII SMP Negeri 1 Cingambul Kabupaten Majalengka. Skripsi IAIN Syekh Nurjati Cirebon.

Nursih, Aat. 2017. Pengembangan Program Sekolah Berbasis Adiwiyata Dalam Upaya Pelestarian Lingkungan Hidup di SMA Negeri 3 Kota Cirebon. Skripsi IAIN Syekh Nurjati Cirebon.

Othenk, Abdurahmat. 2007.Efektivitas Teknik Sistem Informasi. Surabaya : Prima Printing.

Pidarta, Made.2009. Landasan Kependidikan .Jakarta: Rineka Cipta.

Riduwan. 2006. Dasar - dasar Statistik. Bandung: Alfabeta.

Suharsimi, Arikunto. 2006. Prosedur Suatu Pendekatan Praktek. Jakarta: Rineka Cipta.

Salim, Emil,.1991. Pembangunan Berkelanjutan (Strategi Alternatif dalam Pembangunan Dekade Sembilan Puluhan). Jakarta : Prisma.

Sugiyono. 2015. Statistik Untuk Penelitian. Bandung: Alfabeta.

Sarwono, Jonathan. 2015. Rumus-rumus Populer dalam SPSS 22 Untuk Riset Skripsi. Yogyakarta : Andi Offset.

Jurnal Edueksos Vol.VIII, No. 2, Desember 2019

The journal of social and economics education 
Sulistya, P. 2006. Mendidik Generasi Muda Dengan Pendidikan Lingkungan (online). Jakarta : Rineka Cipta.

Suwarno, W.2006. Dasar-Dasar Ilmu Pendidikan. Yogyakarta : AR-Ruzz Media.

Sudijono, Anas, 2009. Pengantar Evaluasi Pendidikan. Jakarta: Raja Grapindo.

Tika, Pabundu. 2006. Metodologi Riset Bisnis. Jakarta :Bumi Aksara.

Thobroni. 2017. Belajar \& Pembelajaran. Yogyakarta: Ar-Ruzz Media.

Uno, Hamzah B. 2008.Perencanaan Pembelajaran. Jakarta :Bumi Aksara.

Usman, Husaini. 2009. Metode Penelitian Sosial. Jakarta: Bumi Aksara.

Vera, Adelia.2012. Metode Mengajar Anak Di Luar Kelas (Outdoor Study). Yogyakarta : Diva Press.

Widiasworo, Erwin. 2017. Strategi Dan Metode Mengajar Siswa Di Luar Kelas (Outdoor Learning). Yogyakarta :Ar-Ruzz Media 